\title{
Serum Vitamin D Associated with Insulin Secretory Function in Impaired Fasting Glucose Subjects
}

\author{
A. K. M. Shahidur Rahman1, Md. Arifuzzaman Sohel2, Farjana Rahman Bhuiyan², \\ Fahad Al Shatil Ashrafee1, Md. Kabir Hossain', Syed Fazlul Islam', \\ Mohammad Ibrahim Ali ${ }^{3}$, Rahelee Zinnat ${ }^{2}$
}

\begin{abstract}
${ }^{1}$ Department of Nephrology, Bangabandhu Sheikh Mujib Medical University (BSMMU), Dhaka, Bangladesh ${ }^{2}$ Department of Biochemistry \& Cell Biology, Bangladesh University of Health Sciences (BUHS), Dhaka, Bangladesh ${ }^{3}$ Department of Urology, Dhaka Medical College Hospital, Dhaka, Bangladesh

Email: shahidurrahman70@gmail.com
\end{abstract}

How to cite this paper: Shahidur Rahman, A.K.M., Sohel, Md.A., Bhuiyan, F.R., Ashrafee, F. Al S., Hossain, Md.K., Islam, S.F., Ali, M.I. and Zinnat, R. (2019) Serum Vitamin D Associated with Insulin Secretory Function in Impaired Fasting Glucose Subjects. Journal of Biosciences and Medicines, 7, 83-98.

https://doi.org/10.4236/jbm.2019.71008

Received: December 3, 2018

Accepted: January 7, 2019

Published: January 10, 2019

Copyright $\odot 2019$ by authors and Scientific Research Publishing Inc. This work is licensed under the Creative Commons Attribution International License (CC BY 4.0).

http://creativecommons.org/licenses/by/4.0/

\begin{abstract}
Background: Impaired fasting glucose (IFG) is a prediabetic condition and is a high-risk state for developing diabetes and associated complications. The aim of this study was to explore the association of vitamin D with insulin secretory function among the IFG subjects. Materials and Methods: This was a prospective cross-sectional study conducted in the Department of Biochemistry and Cell Biology, Bangladesh University of Health Sciences (BUHS), Dhaka, Bangladesh; from June 2016 to May 2017, on forty-six (46) IFG subjects. Serum blood glucose was measured by glucose-oxidase method, Fasting serum lipid profile (Total cholesterol, TG and HDL-c); liver enzyme like alanine aminotransferase (ALT) was measured by enzymatic-colorimetric method; Serum creatinine was measured by colorimetric kinetic method; Serum Insulin and vitamin $\mathrm{D}[25(\mathrm{OH}) \mathrm{D}]$ were measured by ELISA method; insulin secretory capacity (HOMA\%B) and insulin sensitivity (HOMA\%S) were calculated by Homeostasis Model Assessment (HOMA) using HOMA-CIGMA software. Results: Among 46 IFG subjects, 22 (47.8\%) were male and rest 24 $(52.2 \%)$ were female and their mean age was $40( \pm 8)$ years. Mean fasting serum glucose level of the study subjects was $6.33( \pm 0.23) \mathrm{mmol} / \mathrm{l}$ and mean postprandial serum glucose level was $7.23( \pm 0.41) \mathrm{mmol} / \mathrm{l}$. Mean serum vitamin D level of the study subjects was $26.54( \pm 8.83) \mathrm{ng} / \mathrm{ml}$. Mean HOMA\%S, HOMA\%B and HOMA\%IR of the total study subjects were $48.34( \pm 16.70)$, $102.16( \pm 23.13)$ and $2.28( \pm 0.70)$ respectively. Insulin secretory capacity (HOMA\%B) was significantly higher $(\mathrm{p}=0.047)$ in the subjects having higher vitamin $\mathrm{D}[25(\mathrm{OH}) \mathrm{D}$ level $\geq 20 \mathrm{ng} / \mathrm{ml}]$ compared to the subjects having lower
\end{abstract}


vitamin D [25(OH)D levels < $20 \mathrm{ng} / \mathrm{ml}$ ]. Conclusion: High prevalence of hypovitaminosis D exists among IFG subjects. Vitamin D is associated with insulin secretory function in IFG subjects. Population based prospective studies using larger sample size should be done to confirm the results.

\section{Keywords}

Impaired Fasting Glucose (IFG), Insulin Secretory Capacity, Insulin Sensitivity, Prediabetes, Vitamin D

\section{Introduction}

Impaired fasting glucose (IFG) is the state of an individual whose fasting blood glucose levels are consistently elevated above normal but are not high enough to be considered as having diabetes mellitus. IFG is defined as elevated fasting plasma glucose (FPG) concentration $\geq 110 \mathrm{mg} / \mathrm{dl}$ and $<125 \mathrm{mg} / \mathrm{dl}(6.1-6.9$ $\mathrm{mmol} / \mathrm{L}$ ) [1]. Impaired fasting glucose (IFG) [Like impaired glucose tolerance (IGT)] is a prediabetic condition and is a high-risk state for developing diabetes and associated complications [2]. Globally 5\% - 10\% people with prediabetes progress to diabetes each year [3]. Prediabetes is a common disorder in most populations. The reported prevalence of prediabetes appears to vary among populations with different ethnic backgrounds. Currently 314 million people are affected with prediabetes all over the world, and by 2025, it is estimated that approximately 500 million people will have prediabetes [4].

In healthy people blood glucose is strictly regulated. Fasting glucose is maintained between 3.9 and $5.6 \mathrm{mmol} / \mathrm{L}$ and the post-meal increases rarely exceed 3 $\mathrm{mmol} / \mathrm{L}$. During the development of prediabetes, this homeostasis of fasting and post-load glucose becomes abnormal. Subjects with prediabetes manifest both core defects that are characteristic of type 2 diabetes i.e. insulin resistance and $\beta$-cell dysfunction. Study reveals that, IFG depends primarily on defective insulin secretion, and IGT on insulin resistance [5]. The first-phase insulin secretion decreases in subjects with IFG [6] [7], whereas both first and second phases of insulin secretion are abnormal in those with IGT [8]. The pathophysiology of IFG seems to include the following key defects: reduced hepatic insulin sensitivity, stationary $\beta$-cell dysfunction and/or chronic low $\beta$-cell mass, altered glucagon-like peptide-1 secretion and inappropriately elevated glucagon secretion. The aetiology of IFG is predominantly related to genetic factors, smoking and male sex [9].

Vitamin D is a fat soluble vitamin and is obtained from diet (oily fish or fortified dairy products), dietary supplements and sun exposure. Vitamin D is a multifunctional hormone that can affect many essential biological functions, ranging from immune regulation to mineral ion metabolism. Although the major function of vitamin $\mathrm{D}$ is to maintain calcium and phosphate homeostasis and to promote bone mineralization, many extraskeletal roles for vitamin $\mathrm{D}$ have been 
identified [10]. Recently it has been reported that vitamin D inadequacy is associated with significant coronary artery stenosis [11]. Some studies have shown that low vitamin $\mathrm{D}$ status is associated with an increased risk of various diseases, such as cancer, hypertension, and cardiovascular disease [10]. Vitamin D has been associated with the functioning and regulation of over 200 genes [12]. Vitamin $\mathrm{D}$ exerts its action in a variety of cell types through vitamin $\mathrm{D}$ receptor (VDR). Molecular evidence have documented that pancreatic $\beta$-cells express both cytolic/nuclear VDR, thus enhances $\beta$-cells function [13]. Additionally, vitamin $\mathrm{D}$ protects pancreatic $\beta$-cells from immune attack [14]. Vitamin D $[25(\mathrm{OH}) \mathrm{D}]$ inhibits the release of the pro-inflammatory cytokines, TNF $\alpha$ and regulates the activity of TLR 2 and TLR 4 proteins [14]. Also some other studies have shown that vitamin D may play a functional role on glucose tolerance through its effects on insulin secretion and insulin sensitivity [15].

Dietary vitamin $\mathrm{D}[25(\mathrm{OH}) \mathrm{D}]$ is absorbed in the small intestine and incorporated into chylomicrons, then travels to the liver, bound to vitamin D binding protein and in continued association with chylomicrons and lipoproteins, where it and endogenously synthesized cholecalciferol are metabolized. During exposure to sunlight, the solar ultraviolet B (UVB) photons with 290 to $315 \mathrm{~nm}$ wavelengths are absorbed by 7-dehydrocholesterol in the skin, which is then converted into previtamin $\mathrm{D}$ which is converted by a thermal reaction into vitamin $\mathrm{D}[25(\mathrm{OH}) \mathrm{D}]$. In the kidney, the $25(\mathrm{OH}) \mathrm{D}$ can undergo two different hydroxylation reactions (catalyzed by different hydroxylases:1 $\alpha$-hydroxylase and 24-hydroxylase), generating the active $1,25(\mathrm{OH}) 2 \mathrm{D}$ (calcitriol), and $24,25(\mathrm{OH}) 2 \mathrm{D}$, the inactive form.

During recent years, a considerable body of evidence has emerged suggesting that vitamin D may have an impact on the development of prediabetes. Data from the third National Health and Nutrition Examination Survey (NHANES III, 1988-1994) revealed that vitamin D deficiency was associated with an increased risk of type 2 diabetes. Conversely, in the Nurses' Health Study, Pittas AG et al., (2006) reported a 33\% decreased risk of type 2 diabetes in women with high vitamin D intake compared to women with low intake [16]. Association of vitamin $\mathrm{D}[25(\mathrm{OH}) \mathrm{D}]$ in insulin sensitivity among prediabetic IGT subjects have already been documented [17] [18]. Low serum 25-hydroxyvitamin D $[25(\mathrm{OH}) \mathrm{D}]$ concentrations in non-diabetic adults have been shown to correlate with impaired glucose tolerance and an increased risk of type 2 diabetes, [18] [19] [20] while a correlation between hypovitaminosis D and insulin resistance (IR) has been identified in pregnant women and obese adolescents [21] [22]. A 10 -year prospective study on non-diabetic adults identified an inverse relationship between baseline serum 25(OH)D concentrations and later risk of IR [23]. Another study identified an inverse association between circulating vitamin $\mathrm{D}$ $[25(\mathrm{OH}) \mathrm{D}]$ and $\beta$-cell function in non-diabetic adults [24]. A negative effect of hypovitaminosis $\mathrm{D}[25(\mathrm{OH}) \mathrm{D}]$ on $\beta$-cell function has been reported among prediabetic adults [17] [18] [25]. Low vitamin D [25(OH)D] levels are associated with a higher risk of IFG in obese adolescents has also been reported 
[26]. But there is scarce evidence on association between vitamin $\mathrm{D}$ $[25(\mathrm{OH}) \mathrm{D}]$ with insulin secretory function in impaired fasting glucose (IFG) subjects.

\section{Materials and Methods}

A prospective cross-sectional study has been conducted in the Department of Biochemistry and Cell Biology, Bangladesh University of Health Sciences (BUHS), Darus Salam, Mirpur, Dhaka, Bangladesh; over a period of one year from June 2016 to May 2017. Forty-six (46) impaired fasting glucose (IFG) subjects were purposively collected. Data about socio-demographics were carefully taken; blood pressure, height, weight were appropriately measured; BMI and WHR were calculated accordingly. Serum analysis was done by appropriate procedure and methods. Serum blood glucose was measured by glucose-oxidase method; Fasting serum lipid profile (Total cholesterol, TG and HDL-c) and liver enzyme like Alanine Aminotransferase (ALT) were measured by enzymatic-colorimetric method; Serum creatinine was measured by colorimetric kinetic method; Serum Insulin and vitamin D $[25(\mathrm{OH}) \mathrm{D}]$ were measured by ELISA method; insulin secretory capacity (HOMA\%B) and insulin sensitivity (HOMA\%S) were calculated by Homeostasis Model Assessment (HOMA) using HOMA-CIGMA software. Student's unpaired " $t$ " test, Pearson's correlation coefficient and logistic regression analysis was done for statistical analysis using SPSS package.

This study was approved by the ethical review committee of Bangladesh University of Health Sciences (BUHS), Darus Salam, Mirpur, Dhaka, Bangladesh.

\section{Procedure}

\subsection{Recruitment of the Subjects}

According to WHO criteria forty-six (46) IFG subjects were collected on Saturday, Monday, and Wednesday of the week between 8:00 am to 12:00 noon from the Out-Patient Department (OPD) of Bangladesh Institute of Health Sciences (BIHS) Hospital, Darus Salam, Mirpur, Dhaka, Bangladesh. After taking brief history, preliminary selection was done, and the purpose of the study was explained in details to each subject and their verbal consent was taken. They were advised to take unrestricted carbohydrate diet, to do normal physical activities and to avoid drugs and vitamin supplementations that significantly interfere blood glucose level (like glucocorticoids, oral contraceptives containing levonorgestrel or high-dose estrogen, phenytoin, high-dose thiazide diuretics, etc.) for 3 days. They were also advised to abandon the program if they became sick. Then they were requested to report to BUHS Biochemistry laboratory after 3 days at morning between 8.00-10.00 am following an overnight (8 - 12 hours) fasting. When the subjects reported, informed written consent was taken from all participants. A predesigned case record form was used to record relevant clinical, medical, demographic, socio-economic data (age, sex, educational sta- 
tus, and occupational status) from the consenting subjects.

\subsection{Sample Collection and Storage}

Overnight fasting (8 - 12 hours) blood was collected between 8.00-9.00 am. Venous blood $(6 \mathrm{ml})$ was obtained by venipuncture following standard procedure. Subjects were then allowed to drink glucose (75 gm in $300 \mathrm{ml}$ of water). Then they were requested not to take any food \& beverage and be rested for two hours. After 2 hours of glucose intake the second blood sample $(3.00 \mathrm{ml}$ venous blood) was taken. Fasting and postprandial blood samples were taken into plain tube $(6 \mathrm{cc})$, allowed to clot for 30 minutes and serum was separated by centrifugation for $10 \mathrm{~min}$ at $3000 \mathrm{rpm}$ and then the serum was collected at least $600 \mu \mathrm{l}$ in each of four aliquots. Blood samples were maintained at $4^{\circ} \mathrm{C}$ until separation and serum was frozen at $-30^{\circ} \mathrm{C}$ within an hour of sample collection. One aliquot was assayed for fasting serum glucose, serum glucose 2 hours after $75 \mathrm{gm}$ oral glucose load, S. triglyceride, total cholesterol, HDL cholesterol, S. creatinine, ALT by appropriate procedure within a week of sample collection. Second aliquot was kept frozen for insulin and third aliquot for vitamin $\mathrm{D}[25(\mathrm{OH}) \mathrm{D}]$ measurement respectively. The remaining aliquot was kept frozen at $-30^{\circ} \mathrm{C}$ for further measurement. Serum was not allowed to be thawed until the assay was performed.

Insulin secretory function (HOMA\%B) and insulin sensitivity (HOMA\%S) was calculated from fasting serum glucose and insulin values by Homeostasis Model Assessment (HOMA) using HOMA-CIGMA software.

\subsection{Analytical Methods}

Biochemical measurements were carried out at the Biochemistry Lab, Dept of Biochemistry \& Cell Biology, Bangladesh University of Health sciences (BUHS), Darus Salam, Mirpur, Dhaka, Bangladesh.

The following laboratory investigations were done for each of the study subject-

- Serum blood glucose was measured by glucose-oxidase method in the automatic analyzer (Siemens Dimension-RXL, max, Siemens, USA).

- Fasting serum lipid profile (Total cholesterol, TG and HDL-c) and liver enzyme like Serum Alanine Aminotransferase (ALT) were measured by enzymatic-colorimetric method in the automatic analyzer (Siemens Dimension-RXL, max, Siemens, USA).

- Serum creatinine was measured by colorimetric kinetic method in the automatic analyzer (Siemens Dimension-RXL, max, Siemens, USA).

- Serum Insulin and vitamin D $[25(\mathrm{OH}) \mathrm{D}]$ were measured by ELISA method (DRG-International, Germany).

- Insulin secretory function (HOMA\%B) and insulin sensitivity (HOMA\%S) were calculated by Homeostasis Model Assessment (HOMA) using HOMA-CIGMA software. 


\subsection{Statistical Analysis}

All the collected data were rechecked, coded and entered into a database using Statistical Package for Social Science (SPSS) for Windows version 19 software (SPSS Inc., Chicago, ILL). Analysis was done targeting the study objectives by considering the indicators. Simple descriptive method was used for representing variables that is, frequencies along with percentages or mean with standard deviation as necessary. Comparison between two groups was done using Student's unpaired " $\mathrm{t}$ " test for normally distributed continuous variables. Correlation analysis between variables was examined by the Pearson's correlation test. Multiple linear regression analysis was done where appropriate. $\mathrm{p}$ value $<0.05$ was considered as significant.

\section{Results}

Among forty-six (46) impaired fasting glucose (IFG) subjects, 22(47.8\%) were male and rest $24(52.2 \%)$ were female and their mean $( \pm \mathrm{SD})$ age was $40( \pm 8)$ years. Mean $( \pm \mathrm{SD}) \mathrm{BMI}\left(\mathrm{kg} / \mathrm{m}^{2}\right)$ and WHR of the study population was 26.68 $( \pm 4.99) \mathrm{kg} / \mathrm{m}^{2}$ and $0.95( \pm 0.07)$. Mean $( \pm \mathrm{SD})$ systolic blood pressure $(\mathrm{SBP})$ and diastolic blood pressure DBP) of the study population was $113.26( \pm 9.67) \mathrm{mm}$ of $\mathrm{Hg}$ and $75.43( \pm 7.52) \mathrm{mm}$ of $\mathrm{Hg}$ respectively.

The anthropometric and clinical characteristics of the study subjects shown in following table (Table 1).

Mean $( \pm$ SD) fasting serum glucose level of the study subjects was $6.33( \pm 0.23)$ $\mathrm{mmol} / \mathrm{l}$ and mean $( \pm \mathrm{SD})$ postprandial (2 hour after glucose-AG) serum glucose level was $7.23( \pm 0.41) \mathrm{mmol} / \mathrm{l}$. There was no significant abnormality in serum lipid profile of the study subjects. Their renal function [mean $( \pm$ SD) S. creatinine $1.04( \pm 0.15) \mathrm{mg} / \mathrm{dl}]$ and liver function [mean $( \pm \mathrm{SD})$ Serum Alanine Aminotransferase (ALT) $29.13( \pm 8.94) \mathrm{IU} / \mathrm{L}]$ were within normal limits. Mean $( \pm \mathrm{SD})$ vitamin D level of the study subjects was $26.54( \pm 8.83) \mathrm{ng} / \mathrm{ml}$.

Table 2 shows biochemical characteristics of the study subjects.

Mean $( \pm$ SD) fasting serum insulin of the total IFG subjects was $16.93( \pm 5.37)$ $\mu \mathrm{IU} / \mathrm{ml}$. Mean $( \pm \mathrm{SD})$ HOMA\%S, HOMA\%B and HOMA\%IR of the total study subjects were $48.34( \pm 16.70), 102.16( \pm 23.13)$ and $2.28( \pm 0.70)$ respectively (Table 3).

Table 1. Anthropometric \& clinical characteristics of the IFG subjects $(n=46)$.

\begin{tabular}{cc}
\hline Variables & Mean \pm SD \\
\hline Age (Years) & $40 \pm 8$ \\
BMI $\left(\mathrm{kg} / \mathrm{m}^{2}\right)$ & $26.68 \pm 4.99$ \\
WHR & $0.95 \pm 0.07$ \\
SBP $(\mathrm{mm}$ of $\mathrm{Hg})$ & $113.26 \pm 9.67$ \\
DBP $(\mathrm{mm}$ of $\mathrm{Hg})$ & $75.43 \pm 7.52$
\end{tabular}

BMI $=$ Body Mass Index; WHR $=$ Waist Hip Ratio; $\mathrm{SBP}=$ Systolic Blood Pressure; DBP $=$ Diastolic Blood Pressure. 
Table 2. Biochemical characteristics of the IFG subjects $(n=46)$.

\begin{tabular}{cc}
\hline Variables & Mean \pm SD \\
FBG $(\mathrm{mmol} / \mathrm{l})$ & $6.33 \pm 0.23$ \\
AG $(\mathrm{mmol} / \mathrm{l})$ & $7.23 \pm 0.41$ \\
TG $(\mathrm{mg} / \mathrm{dl})$ & $165.48 \pm 44.39$ \\
Chol $(\mathrm{mg} / \mathrm{dl})$ & $197.04 \pm 40.92$ \\
HDL-c $(\mathrm{mg} / \mathrm{dl})$ & $44.07 \pm 5.02$ \\
LDL-c $(\mathrm{mg} / \mathrm{dl})$ & $119.87 \pm 38.17$ \\
ALT $(\mathrm{IU} / \mathrm{L})$ & $29.13 \pm 8.94$ \\
S. Creatinine $(\mathrm{mg} / \mathrm{dl})$ & $1.04 \pm 0.15$ \\
S. Vitamin D $(\mathrm{ng} / \mathrm{ml})$ & $26.54 \pm 8.83$ \\
\hline
\end{tabular}

FBG = Fasting Blood Glucose; AG = After Glucose ( 2 hours after glucose)/PPBS (Post-Prandial Blood Sugar; $\mathrm{TG}=$ Triglyceride; Chol $=$ Cholesterol; HDL-c $=$ High Density Lipoprotein Cholesterol LDL- $\mathrm{c}=$ Low Density Lipoprotein Cholesterol; ALT = Alanine Aminotransferase.

Table 3. Insulinemic status of the IFG subjects $(n=46)$.

\begin{tabular}{cc}
\hline Variables & Mean \pm SD \\
\hline S Insulin $(\mu \mathrm{IU} / \mathrm{ml})$ & $16.93 \pm 5.37$ \\
HOMA\%S & $48.34 \pm 16.70$ \\
HOMA\%B & $102.16 \pm 23.13$ \\
HOMA\% IR & $2.28 \pm 0.70$ \\
\hline
\end{tabular}

The Homeostasis Model Assessment (HOMA) estimates steady state beta cell function (\%B) and insulin sensitivity (\%S), as percentages of a normal reference population. HOMA IR (insulin resistance) which is the reciprocal of $\% \mathrm{~S}(100 / \% \mathrm{~S})$.

Among the total study population (IFG subjects, $n=46), 13$ subjects $(28.26 \%)$ were serum vitamin $\mathrm{D}$ deficient [serum $25(\mathrm{OH}) \mathrm{D}<20 \mathrm{ng} / \mathrm{ml}$ ], 17 subjects (36.95\%) had insufficient serum vitamin D [serum 25(OH)D = $20.1 \sim 30 \mathrm{ng} / \mathrm{ml}$ ] level and rest 16 subjects (34.78\%) were sufficient serum vitamin D [serum $25(\mathrm{OH}) \mathrm{D}>30.1 \mathrm{ng} / \mathrm{ml}]$ level (Table 4$)$.

Subjects were sub-grouped according to their vitamin D [Serum 25(OH)D concentration] level (cut-off point $20 \mathrm{ng} / \mathrm{ml}$ ). No significant variation was found in anthropometric \& clinical characteristics according to the cut-off point $[<20$ $\mathrm{ng} / \mathrm{ml}$ of $25(\mathrm{OH}) \mathrm{D}$ levels and $\geq 20 \mathrm{ng} / \mathrm{ml}$ of $25(\mathrm{OH}) \mathrm{D}$ levels] among the IFG subjects (Table 5).

There was no significant difference in biochemical characteristics according to cut-off point [ $<20 \mathrm{ng} / \mathrm{ml}$ of $25(\mathrm{OH}) \mathrm{D}$ levels and $\geq 20 \mathrm{ng} / \mathrm{ml}$ of $25(\mathrm{OH}) \mathrm{D}$ levels] among the total IFG subjects (Table 6).

Insulin secretory capacity (HOMA\%B) was significantly higher $(\mathrm{p}=0.047)$ in the subjects having higher vitamin $\mathrm{D}[25(\mathrm{OH}) \mathrm{D}$ level $\geq 20 \mathrm{ng} / \mathrm{ml}(\mathrm{n}=33)]$ compared to the subjects having lower vitamin D $[25(\mathrm{OH}) \mathrm{D}$ levels $<20 \mathrm{ng} / \mathrm{ml}(\mathrm{n}$ $=13)]$. 
Table 4. Frequency \& percentage of vitamin D levels in IFG subjects $(n=46)$.

\begin{tabular}{ccc}
\hline S. vitamin D level (ng/ml) & Number of subjects & Percent (\%) \\
\hline$<20$ & 13 & 28.26 \\
$20-30$ & 17 & 36.95 \\
$>30$ & 16 & 34.78 \\
Total & 46 & 100.00 \\
\hline
\end{tabular}

Table 5. Anthropometric \& clinical characteristics according to cut-off point $20 \mathrm{ng} / \mathrm{ml}$ of $25(\mathrm{OH}) \mathrm{D}$ levels among the IFG subjects.

\begin{tabular}{|c|c|c|c|}
\hline \multirow{2}{*}{ Variables } & \multicolumn{2}{|c|}{ Serum $25(\mathrm{OH}) \mathrm{D}$ concentration } & \multirow{2}{*}{$\mathrm{t} / \mathrm{p}$ value } \\
\hline & $<20 \mathrm{ng} / \mathrm{ml}(\mathrm{n}=13)$ & $\geq 20 \mathrm{ng} / \mathrm{ml}(\mathrm{n}=33)$ & \\
\hline BMI $\left(\mathrm{kg} / \mathrm{m}^{2}\right)$ & $26 \pm 3$ & $26 \pm 6$ & $-0.305 / 0.762$ \\
\hline WHR & $0.92 \pm 0.05$ & $0.95 \pm 0.07$ & $-1.364 / 0.179$ \\
\hline SBP $(\mathrm{mm}$ of $\mathrm{Hg})$ & $112 \pm 11$ & $114 \pm 9$ & $-0.754 / 0.455$ \\
\hline DBP $(\mathrm{mm}$ of $\mathrm{Hg})$ & $74 \pm 8$ & $76 \pm 7$ & $-0.898 / 0.374$ \\
\hline
\end{tabular}

The level of significance at $\mathrm{p}<0.05$.

Table 6. Biochemical characteristics according to cut-off point $<20 \mathrm{ng} / \mathrm{ml}$ of $25(\mathrm{OH}) \mathrm{D}$ levels and $\geq 20 \mathrm{ng} / \mathrm{ml}$ of $25(\mathrm{OH}) \mathrm{D}$ levels among the total IFG subjects.

\begin{tabular}{cccc}
\hline \multirow{2}{*}{ Variables } & \multicolumn{2}{c}{ Serum 25 (OH) D concentration } & \multirow{2}{*}{ t/p value } \\
\cline { 2 - 3 } & $<\mathbf{2 0 ~ n g / m l ~ ( n = 1 3 )}$ & $\geq 20 \mathrm{ng} / \mathrm{ml}(\mathrm{n}=\mathbf{3 3})$ & \\
\hline FBG $(\mathrm{mmol} / \mathrm{l})$ & $6.43 \pm 0.31$ & $6.29 \pm 0.18$ & $1.541 / 0.062$ \\
AG $(\mathrm{mmol} / \mathrm{l})$ & $6.96 \pm 0.43$ & $7.34 \pm 0.35$ & $-2.873 / 0.003$ \\
TG $(\mathrm{mg} / \mathrm{dl})$ & $150.77 \pm 44.0$ & $171.27 \pm 43.85$ & $-1.427 / 0.161$ \\
Chol $(\mathrm{mg} / \mathrm{dl})$ & $197.62 \pm 35.23$ & $196.82 \pm 43.46$ & $0.059 / 0.953$ \\
HDL-c $(\mathrm{mg} / \mathrm{dl})$ & $45.54 \pm 4.14$ & $43.48 \pm 5.27$ & $1.257 / 0.215$ \\
LDL-c $(\mathrm{mg} / \mathrm{dl})$ & $121.89 \pm 31.22$ & $119.08 \pm 41.0$ & $0.223 / 0.825$ \\
ALT $(\mathrm{U} / \mathrm{L})$ & $24.85 \pm 5.63$ & $30.82 \pm 9.49$ & $-2.629 / 0.040$ \\
S. Creatinine (mg/dl) & $0.92 \pm 0.16$ & $1.08 \pm 0.11$ & $-3.254 / 0.1$ \\
S. Vitamin D (ng/ml) & $24.85 \pm 5.63$ & $30.82 \pm 9.49$ & $-10.963 / 0.1$ \\
\hline
\end{tabular}

The level of significance at $\mathrm{p}<0.05$.

There was no significant difference in Insulinemic status according to cut-off point $[<20 \mathrm{ng} / \mathrm{ml}$ of $25(\mathrm{OH})$ D levels and $\geq 20 \mathrm{ng} / \mathrm{ml}$ of $25(\mathrm{OH}) \mathrm{D}$ levels] among the total IFG subjects (Table 7).

Pearson's correlation analysis were performed to cut-off point $<20 \mathrm{ng} / \mathrm{ml}$ for serum vitamin $\mathrm{D}[25(\mathrm{OH}) \mathrm{D}]$ with other anthropometric \& biochemical variables among the IFG subjects $(\mathrm{n}=13)$. Where $<20 \mathrm{ng} / \mathrm{ml}$ of 25(OH)D levels showed no significant association between vitamin D [25(OH)D] and other variables among these IFG subjects (Table 8). 
Table 7. Insulinemic status according to cut-off point $<20 \mathrm{ng} / \mathrm{ml}$ of $25(\mathrm{OH}) \mathrm{D}$ levels and $\geq 20 \mathrm{ng} / \mathrm{ml}$ of $25(\mathrm{OH}) \mathrm{D}$ levels among the total IFG subjects.

\begin{tabular}{cccc}
\hline \multirow{2}{*}{ Variables } & \multicolumn{2}{c}{ Serum 25(OH)D concentration } & \multirow{2}{*}{ t/p value } \\
\cline { 2 - 3 } & $<\mathbf{2 0} \mathbf{~ n g / m l ~}(\mathbf{n}=13)$ & $\geq 20 \mathrm{ng} / \mathrm{ml}(\mathbf{n}=\mathbf{3 3})$ & \\
\hline S Insulin $(\mu \mathrm{IU} / \mathrm{ml})$ & $16.93 \pm 5.37$ & $17.60 \pm 5.57$ & $-1.353 / 0.183$ \\
HOMA\%S & $48.34 \pm 16.70$ & $52.38 \pm 16.01$ & $1.029 / 0.309$ \\
HOMA\%B & $102.16 \pm 23.13$ & $106.05 \pm 23.83$ & $-2.081 / 0.047$ \\
HOMA IR & $2.28 \pm 0.70$ & $2.37 \pm 0.72$ & $-1.301 / 0.200$ \\
\hline
\end{tabular}

The level of significance at $\mathrm{p}<0.05$.

Table 8. Pearson's correlation according to cut-off point $<20 \mathrm{ng} / \mathrm{ml}$ of $25(\mathrm{OH}) \mathrm{D}$ levels with other variables among the IFG subjects $(n=13)$.

\begin{tabular}{ccc}
\hline Variables & r value & p value \\
\hline Age $(\mathrm{yrs})$ & 0.149 & 0.627 \\
BMI $\left(\mathrm{kg} / \mathrm{m}^{2}\right)$ & -0.111 & 0.717 \\
FBG $(\mathrm{mmol} / \mathrm{l})$ & 0.188 & 0.539 \\
AG $(\mathrm{mmol} / \mathrm{l})$ & 0.409 & 0.165 \\
TG $(\mathrm{mg} / \mathrm{dl})$ & 0.198 & 0.516 \\
ALT $(\mathrm{IU} / \mathrm{L})$ & 0.222 & 0.467 \\
S. Insulin $(\mu \mathrm{IU} / \mathrm{ml})$ & 0.311 & 0.301 \\
HOMA\%S & -0.163 & 0.595 \\
HOMA $\% \mathrm{~B}$ & 0.223 & 0.464 \\
HOMA IR & 0.310 & 0.303 \\
\hline
\end{tabular}

The level of significance at $\mathrm{p}<0.05 ; \mathrm{r}=$ correlation coefficient.

Pearson's correlation analysis were performed to cut-off point $\geq 20 \mathrm{ng} / \mathrm{ml}$ for serum vitamin $\mathrm{D}[25(\mathrm{OH}) \mathrm{D}]$ with other anthropometric \& biochemical variables among the IFG subjects $(\mathrm{n}=33)$. Where $\geq 20 \mathrm{ng} / \mathrm{ml}$ of $25(\mathrm{OH}) \mathrm{D}$ levels showed that there is no significant association between vitamin $\mathrm{D}[25(\mathrm{OH}) \mathrm{D}]$ and other variables among these IFG subjects (Table 9).

Multiple linear regression analysis was done by considering HOMA\%B as dependent variable and BMI, TG and S. vitamin $\mathrm{D}$ as independent variables. Where BMI had a positive association $(\mathrm{p}=0.009)$ with HOMA\%B but TG and $\mathrm{S}$. vitamin D showed no significant association with HOMA\%B after adjusting the confounding variables (Table 10).

Multiple linear regression analysis was done by considering HOMA\%S as dependent variable and BMI, TG and S. vitamin $\mathrm{D}$ as independent variables. Where BMI, TG and S. vitamin D showed no significant association with HOMA\%S after adjusting the confounding variables (Table 11).

\section{Discussion}

Impaired fasting glucose (IFG) is a prediabetic condition and is a transitory state 
Table 9. Pearson's correlation according to cut-off point $\geq 20 \mathrm{ng} / \mathrm{ml}$ of $25(\mathrm{OH}) \mathrm{D}$ levels with other variables among the IFG subjects $(n=33)$.

\begin{tabular}{ccc}
\hline Variables & r value & p value \\
\hline Age $(\mathrm{yrs})$ & 0.287 & 0.106 \\
BMI $\left(\mathrm{kg} / \mathrm{m}^{2}\right)$ & 0.034 & 0.851 \\
FBG $(\mathrm{mmol} / \mathrm{l})$ & -0.016 & 0.930 \\
AG $(\mathrm{mmol} / \mathrm{l})$ & 0.344 & 0.050 \\
TG $(\mathrm{mg} / \mathrm{dl})$ & 0.054 & 0.766 \\
ALT $(\mathrm{IU} / \mathrm{L})$ & 0.182 & 0.310 \\
S Insulin $(\mu \mathrm{IU} / \mathrm{ml})$ & -0.075 & 0.679 \\
HOMA\%S & 0.055 & 0.762 \\
HOMA\%B & -0.068 & 0.707 \\
HOMA IR & -0.076 & 0.674 \\
\hline
\end{tabular}

The level of significance at $\mathrm{p}<0.05 ; \mathrm{r}=$ correlation coefficient.

Table 10. Multiple linear regression analysis taking HOMA\% B as dependent variable among the study participants.

\begin{tabular}{ccc}
\hline Variable & $\beta$ value & p value \\
\hline BMI & 0.385 & 0.009 \\
TG & 0.66 & 0.651 \\
Vitamin D & 0.168 & 0.248
\end{tabular}

$\beta$ for standardized regression coefficient, Dependent Variable: HOMA\% B, p value $<0.05$ was considered statistically significant.

Table 11. Multiple linear regression analysis taking HOMA\% S as dependent variable among the study participants.

\begin{tabular}{ccc}
\hline Variable & $\boldsymbol{\beta}$ value & $\mathrm{p}$ value \\
\hline BMI & -0.277 & 0.070 \\
TG & -0.166 & 0.285 \\
Vit-D & -0.063 & 0.677 \\
\hline
\end{tabular}

$\beta$ for standardized regression coefficient, Dependent Variable: HOMA\% S, p value $<0.05$ was considered statistically significant.

between normoglycemia and diabetes. Therefore IFG carries a variable risk of progression to diabetes. The progression from IFG to diabetes is a time dependent phenomenon and biochemical mechanism of the pathophysiological progression is still unclear. Since insulin resistance and reduced insulin secretion is a risk factor for prediabetes, understanding the role of various nutritional and other modifiable risk factors that may contribute to the pathogenesis of IFG is important.

Vitamin $\mathrm{D}$ is a multifunctional hormone that can affect many essential biological functions, ranging from immune regulation to mineral ion metabolism. 
Although the major function of vitamin D is to maintain calcium and phosphate homeostasis and to promote bone mineralization, many extra-skeletal roles for vitamin D have been identified [10].

During recent years, a novel association between vitamin D [25(OH)D] deficiency and prediabetes has been proposed. There are evidences to suggest that altered vitamin $\mathrm{D}$ and calcium homeostasis may also play a role in the development of type 2 Diabetes Mellitus (DM) [27]. In a study by Lim S et al. (2013) on 1080 non-diabetic Asian population at high risk of T2DM, showed that $25(\mathrm{OH}) \mathrm{D}$ deficiency had an incidence of T2DM development 3.4 times that in those with sufficient levels, even after adjustment for obesity, dynamic measure of insulin resistance and pancreatic $\beta$-cell function, and other known risk factors for T2DM [28].

It is known that $\beta$-cell dysfunction is an important phenomenon of IFG subjects. There are several lines of evidence supporting a role for vitamin $\mathrm{D}$ on pancreatic $\beta$-cell function [29] [30]. The circulating concentration of 25-hydroxyvitamin D $[25(\mathrm{OH}) \mathrm{D}]$ is the common biomarker used to assess vitamin D status [31]. An association between vitamin $\mathrm{D}$ deficiency and $\beta$-cell dysfunction has been reported in healthy and glucose tolerant subjects, non diabetic people, and patients with type 2 diabetes [32]. Interestingly, many studies have revealed that vitamin D3 (Calcitriol) has a role in the synthesis and the secretion of insulin by receptor mediated molecular mechanisms [33] [34]. Identifying preventable risk factors associated with IFG subjects is important in the prevention of progression to diabetes mellitus. Therefore the aim of the present study was to correlate the serum 25 -hydroxy vitamin $\mathrm{D}[25(\mathrm{OH}) \mathrm{D}]$ with $\beta$-cell function in a group of subjects with impaired fasting glycemia.

A group of middle aged (mean age 40 years) IFG subjects were included in this study to investigate the association of vitamin $\mathrm{D}[25(\mathrm{OH}) \mathrm{D}]$ with insulin secretion and insulin sensitivity. Among the total study population 13 subjects (28.3\%) were serum vitamin D deficient, 17 subjects (37\%) had insufficient serum vitamin D level and rest 16 subjects (34.8\%) were sufficient serum vitamin D level. So majority (65.21\%) of impaired fasting glucose (IFG) subjects have low serum vitamin D $[25(\mathrm{OH}) \mathrm{D}]$ level. The Mean $( \pm \mathrm{SD})$ vitamin $\mathrm{D}[25(\mathrm{OH}) \mathrm{D}]$ level of our study subjects was $26.54 \pm 8.83 \mathrm{ng} / \mathrm{ml}$, which reflects the usual vitamin D status of our healthy population. This finding was consistent with study done on Asian population and they demonstrated that in South Asia, $80 \%$ of the apparently healthy population is deficient in vitamin $\mathrm{D}(<20 \mathrm{ng} / \mathrm{ml})$ and up to $40 \%$ of the population is severely deficient $(<9 \mathrm{ng} / \mathrm{ml})$ [35]. In a recent study in India by Vinodhini VM et al. (2014) found insufficient vitamin D level $(<30$ $\mathrm{ng} / \mathrm{ml}$ ) in IFG subjects [36].

Many studies have revealed an association of low vitamin D [25(OH)D] with obesity. A recent study reported that body mass index (BMI) is inversely related to circulating levels of vitamin D [25(OH)D] [37]. In another study it was found that higher BMI leads to lower vitamin D status, providing evidence 
for the role of obesity as a causal risk factor for the development of vitamin D deficiency. Some studies have found that BMI is the key confounding factor, because obesity is correlated with low vitamin D and high T2DM risk [38] [39] [40]. Hyppönen and Power (2006), in a British birth cohort study of 25(OH)D and glucose homeostasis, noted that body size was a strong determinant of 25(OH)D levels with concentrations suboptimal in obese patients, and suggested an association between vitamin $\mathrm{D}$ status and diabetes [41]. Other reports have noted decreased bioavailability of vitamin D [25(OH)D] in obesity [42]. Observational studies have reported an increased risk of vitamin D deficiency in those who are obese; however, the underlying explanations and direction of causality are unclear [43]. In the present study no such association was found between BMI and active vitamin D. As the IFG subjects in the present study were not obese but overweight $(\mathrm{BMI}=27)$ the inverse association of vitamin $\mathrm{D}$ with $\mathrm{BMI}$ was not observed.

Vitamin D deficiency is thought to influence the pathogenesis of prediabetes by affecting either insulin sensitivity and $\beta$-cell dysfunction or both. In present study HOMA\%B of subjects having vitamin D [25(OH)D] level $\geq 20 \mathrm{ng} / \mathrm{ml}(\mathrm{n}=$ 33) had significant positive $(\mathrm{p}=0.047)$ association with serum vitamin $\mathrm{D}$ $[25(\mathrm{OH}) \mathrm{D}]$ in comparison to subjects $(\mathrm{n}=13)$ with vitamin $\mathrm{D}[25(\mathrm{OH}) \mathrm{D}]$ levels $<20 \mathrm{ng} / \mathrm{ml}$. It has been demonstrated that the subjects who have higher vitamin $\mathrm{D}$ level had better $\beta$ (beta)-cell function compared to the subjects having lower vitamin $\mathrm{D}$ level. So vitamin $\mathrm{D}$ is associated with insulin secretory function in IFG subjects. This finding was consistent to previous reports, as showed that higher baseline vitamin $\mathrm{D}[25(\mathrm{OH}) \mathrm{D}]$ independently predicted better $\beta$-cell function and serum vitamin $\mathrm{D}[25(\mathrm{OH}) \mathrm{D}]$ is associated with insulin sensitivity and $\beta$-cell function [44] [45]. There are also several researches that studied the interaction between vitamin $\mathrm{D}$ and $\beta$-cell function. $\beta$-cells express vitamin $\mathrm{D}$ receptor, which can bind to 1,25 -dihydroxyvitamin $\mathrm{D}$. There is vitamin $\mathrm{D}$ acting element in insulin gene promoter region, and vitamin $\mathrm{D}$ can activate the transcription of insulin gene [34] [46]. These studies suggested that vitamin D promotes insulin synthesis and secretion.

\section{Conclusion}

Majority of impaired fasting glucose (IFG) subjects have insufficient vitamin D. No significant correlation exists between BMI, FBS, PPBS \& fasting insulinemic status with vitamin D [25(OH)D] levels. IFG subjects having higher vitamin D level have higher insulin secretory capacity. Vitamin D is associated with insulin secretory function in IFG subjects.

\section{Limitation}

This was a cross sectional study with small sample size, thus our results cannot establish cause \& effective relationship between vitamin D with insulin secretory function in impaired fasting glucose (IFG) subjects. 


\section{Recommendation}

Population based prospective studies using larger sample size should be done to confirm the results and to establish the association between vitamin D with insulin secretory function in impaired fasting glucose (IFG) subjects.

\section{Conflicts of Interest}

The authors declare no conflicts of interest regarding the publication of this paper.

\section{References}

[1] World Health Organization (2006) Definition and Diagnosis of Diabetes Mellitus and Intermediate Hyperglycaemia: Report of a WHO/IDF Consultation.

[2] Morris, D.H., Khunti, K., Achana, F., Srinivasan, B., Gray, L.J., Davies, M.J. and Webb, D. (2013) Progression Rates from $\mathrm{HbA}^{\wedge}$ sub $1 \mathrm{c}^{\wedge}$ 6.0-6.4\% and Other Prediabetes Definitions to Type 2 Diabetes: A Meta-Analysis. Diabetologia, 56, 1489. https://doi.org/10.1007/s00125-013-2902-4

[3] Tabák, A.G., Herder, C., Rathmann, W., Brunner, E.J. and Kivimäki, M. (2012) Prediabetes: A High-Risk State for Diabetes Development. The Lancet, 379, 2279-2290. https://doi.org/10.1016/S0140-6736(12)60283-9

[4] Boyle, J.P., Honeycutt, A.A., Narayan, K.V., Hoerger, T.J., Geiss, L.S., Chen, H. and Thompson, T.J. (2001) Projection of Diabetes Burden through 2050: Impact of Changing Demography and Disease Prevalence in the US. Diabetes Care, 24, 1936-1940. https://doi.org/10.2337/diacare.24.11.1936

[5] Schianca, G.P., Rossi, A., Sainaghi, P.P., Maduli, E. and Bartoli, E. (2003) The Significance of Impaired Fasting Glucose versus Impaired Glucose Tolerance: Importance of Insulin Secretion and Resistance. Diabetes Care, 26, 1333-1337. https://doi.org/10.2337/diacare.26.5.1333

[6] Abdul-Ghani, M.A., Matsuda, M., Jani, R., Jenkinson, C.P., Coletta, D.K., Kaku, K. and DeFronzo, R.A. (2008) The Relationship between Fasting Hyperglycemia and Insulin Secretion in Subjects with Normal or Impaired Glucose Tolerance. American Journal of Physiology-Endocrinology and Metabolism, 295, E401-E406. https://doi.org/10.1152/ajpendo.00674.2007

[7] Kanat, M., Mari, A., Norton, L., Winnier, D., DeFronzo, R.A., Jenkinson, C. and Abdul-Ghani, M.A. (2012) Distinct $\beta$-Cell Defects in Impaired Fasting Glucose and Impaired Glucose Tolerance. Diabetes, 61, 47-53.

https://doi.org/10.2337/db11-0995

[8] Kanat, M., Norton, L., Winnier, D., Jenkinson, C., DeFronzo, R.A. and Abdul-Ghani, M.A. (2011) Impaired Early-But Not Late-Phase Insulin Secretion in Subjects with Impaired Fasting Glucose. Acta Diabetologica, 48, 209. https://doi.org/10.1007/s00592-011-0285-x

[9] Faerch, K., Borch-Johnsen, K., Holst, J.J. and Vaag, A. (2009) Pathophysiology and Aetiology of Impaired Fasting Glycaemia and Impaired Glucose Tolerance: Does It Matter for Prevention and Treatment of Type 2 Diabetes? Diabetologia, 52, 1714-1723. https://doi.org/10.1007/s00125-009-1443-3

[10] Rosen, C.J., Adams, J.S., Bikle, D.D., Black, D.M., Demay, M.B., Manson, J.E., Murad, M.H. and Kovacs, C.S. (2012) The Nonskeletal Effects of Vitamin D: An Endocrine Society Scientific Statement. Endocrine Reviews, 33, 456-492. 
https://doi.org/10.1210/er.2012-1000

[11] Lim, S., Shin, H., Kim, M.J., Ahn, H.Y., Kang, S.M., Yoon, J.W., Choi, S.H., Kim, K.W., Song, J.H., Choi, S.I. and Chun, E.J. (2012) Vitamin D Inadequacy Is Associated with Significant Coronary Artery Stenosis in a Community-Based Elderly Cohort: The Korean Longitudinal Study on Health and Aging. The Journal of Clinical Endocrinology \& Metabolism, 97, 169-178.

https://doi.org/10.1210/jc.2011-1580

[12] Savastano, S., Di Somma, C. and Colao, A. (2013) Vitamin-D \& Prediabetes: A Promising Ménage in the Indian Scenario. The Indian Journal of Medical Research, $138,829$.

[13] Nemere, I., Schwartz, Z., Pedrozo, H., Sylvia, V.L., Dean, D.D. and Boyan, B.D. (1998) Identification of a Membrane Receptor for 1,25-Dihydroxyvitamin D3 Which Mediates Rapid Activation of Protein Kinase C. Journal of Bone and Mineral Research, 13, 1353-1359. https://doi.org/10.1359/jbmr.1998.13.9.1353

[14] Veldman, C.M., Cantorna, M.T. and DeLuca, H.F. (2000) Expression of 1, 25-Dihydroxyvitamin D3 Receptor in the Immune System. Archives of Biochemistry and Biophysics, 374, 334-338. https://doi.org/10.1006/abbi.1999.1605

[15] Palomer, X., González-Clemente, J.M., Blanco-Vaca, F. and Mauricio, D. (2008) Role of Vitamin D in the Pathogenesis of Type 2 Diabetes Mellitus. Diabetes, Obesity and Metabolism, 10, 185-197. https://doi.org/10.1111/j.1463-1326.2007.00710.x

[16] Pittas, A.G., Dawson-Hughes, B., Li, T., Van Dam, R.M., Willett, W.C., Manson, J.E. and Hu, F.B. (2006) Vitamin D and Calcium Intake in Relation to Type 2 Diabetes in Women. Diabetes Care, 29, 650-656. https://doi.org/10.2337/diacare.29.03.06.dc05-1961

[17] Kayaniyil, S., Vieth, R., Retnakaran, R., Knight, J.A., Qi, Y., Gerstein, H.C., Perkins, B., Harris, S.B., Zinman, B. and Hanley, A.J. (2010) Association of Vitamin D with Insulin Resistance and Beta-Cell Dysfunction in Subjects at Risk for Type 2 Diabetes. Diabetes Care, 33, 1379-1381. https://doi.org/10.2337/dc09-2321

[18] Abbasi, F., Blasey, C., Feldman, D., Caulfield, M.P., Hantash, F.M. and Reaven, G.M. (2015) Low Circulating 25-Hydroxyvitamin D Concentrations Are Associated with Defects in Insulin Action and Insulin Secretion in Persons with Prediabetes, 2. The Journal of Nutrition, 145, 714-719. https://doi.org/10.3945/jn.114.209171

[19] Boucher, B.J., Mannan, N., Noonan, K., Hales, C.N. and Evans, S.J. (1995) Glucose Intolerance and Impairment of Insulin Secretion in Relation to Vitamin D Deficiency in East London Asians. Diabetologia, 38, 1239-1245. https://doi.org/10.1007/BF00422375

[20] Gultekin, M., Hekimsoy, Z., Oz, D., Hatiboglu, O., Alarslan, P., Ozmen, B., Onur, E. and Gozukara, C. (2015) Vitamin D Level in Impaired Fasting Glucose and Impaired Glucose Tolerance (Prediabetic) Patients. 17 th European Congress of Endocrinology, 1 May 2015, Vol. 37. https://doi.org/10.1530/endoabs.37.EP339

[21] Alemzadeh, R., Kichler, J., Babar, G. and Calhoun, M. (2008) Hypovitaminosis D in Obese Children and Adolescents: Relationship with Adiposity, Insulin Sensitivity, Ethnicity, and Season. Metabolism, 57, 183-191. https://doi.org/10.1016/j.metabol.2007.08.023

[22] Maghbooli, Z., Hossein-Nezhad, A., Karimi, F., Shafaei, A.R. and Larijani, B. (2008) Correlation between Vitamin D3 Deficiency and Insulin Resistance in Pregnancy. Diabetes/Metabolism Research and Reviews, 24, 27-32. https://doi.org/10.1002/dmrr.737

[23] Forouhi, N.G., Luan, J.A., Cooper, A., Boucher, B.J. and Wareham, N.J. (2008) 
Baseline Serum 25-Hydroxy Vitamin D Is Predictive of Future Glycaemic Status and Insulin Resistance: The MRC Ely Prospective Study 1990-2000. Diabetes, 57, 2619-2626. https://doi.org/10.2337/db08-0593

[24] Yoon, H., Jeon, D.J., Park, C.E., You, H.S. and Moon, A.E. (2016) Relationship between Homeostasis Model Assessment of Insulin Resistance and Beta Cell Function and Serum 25-Hydroxyvitamin D in Non-Diabetic Korean Adults. Journal of Clinical Biochemistry and Nutrition, 59, 139-144. https://doi.org/10.3164/jcbn.15-143

[25] Chiu, K.C., Chu, A., Go, V.L. and Saad, M.F. (2004) Hypovitaminosis D Is Associated with Insulin Resistance and $\beta$ Cell Dysfunction. The American Journal of Clinical Nutrition, 79, 820-825. https://doi.org/10.1093/ajcn/79.5.820

[26] Ekbom, K. and Marcus, C. (2016) Vitamin D Deficiency Is Associated with Prediabetes in Obese Swedish Children. Acta Paediatrica, 105, 1192-1197.

https://doi.org/10.1111/apa.13363

[27] Parker, J., Hashmi, O., Dutton, D., Mavrodaris, A., Stranges, S., Kandala, N.B., Clarke, A. and Franco, O.H. (2010) Levels of Vitamin D and Cardiometabolic Disorders: Systematic Review and Meta-Analysis. Maturitas, 65, 225-236. https://doi.org/10.1016/j.maturitas.2009.12.013

[28] Lim, S., Kim, M.J., Lim, S., Kim, M.J., Choi, S.H., Shin, C.S., Park, K.S., Jang, H.C., Billings, L.K., Meigs, J.B. and Choi, S.H. (2013) Association of Vitamin D Deficiency with Incidence of Type 2 Diabetes in High-Risk Asian Subjects. The American Journal of Clinical Nutrition, 97, 524-530. https://doi.org/10.3945/ajcn.112.048496

[29] Bourlon, P.M., Billaudel, B. and Faure-Dussert, A. (1999) Influence of Vitamin D3 Deficiency and 1,25Dihydroxyvitamin D3 on De Novo Insulin Biosynthesis in the Islets of the Rat Endocrine Pancreas. Journal of Endocrinology, 160, 87-95. https://doi.org/10.1677/joe.0.1600087

[30] Zeitz, U., Weber, K., Soegiarto, D.W., Wolf, E., Balling, R. and Erben, R.G. (2003) Impaired Insulin Secretory Capacity in Mice Lacking a Functional Vitamin D Receptor. The FASEB Journal, 17, 509-511. https://doi.org/10.1096/fj.02-0424fje

[31] Jacques, P.F., Felson, D.T., Tucker, K.L., Mahnken, B., Wilson, P.W., Rosenberg, I.H. and Rush, D. (1997) Plasma 25-Hydroxyvitamin D and Its Determinants in an Elderly Population Sample. The American Journal of Clinical Nutrition, 66, 929-936. https://doi.org/10.1093/ajcn/66.4.929

[32] Isaia, G., Giorgino, R. and Adami, S. (2001) High Prevalence of Hypovitaminosis D in Female Type 2 Diabetic Population. Diabetes Care, 24, 1496-1496. https://doi.org/10.2337/diacare.24.8.1496

[33] Bikle, D.D., Siiteri, P.K., Ryzen, E., Haddad, J.G. and Gee, E. (1985) Serum Protein Binding of 1,25-Dihydroxyvitamin D: A Reevaluation by Direct Measurement of Free Metabolite Levels. The Journal of Clinical Endocrinology \& Metabolism, 61, 969-975. https://doi.org/10.1210/jcem-61-5-969

[34] Maestro, B., Molero, S., Bajo, S., Davila, N. and Calle, C. (2002) Transcriptional Activation of the Human Insulin Receptor Gene by 1, 25-Dihydroxyvitamin D3. Cell Biochemistry and Function, 20, 227-232. https://doi.org/10.1002/cbf.951

[35] Arya, V., Bhambri, R., Godbole, M.M. and Mithal, A. (2004) Vitamin D Status and Its Relationship with Bone Mineral Density in Healthy Asian Indians. Osteoporosis International, 15, 56-61. https://doi.org/10.1007/s00198-003-1491-3

[36] Vinodhini, V.M., Krishnan, A. and Ebenezer William, W. (2014) Vitamin D and Glycemic Control in Impaired Fasting Glycemia. International Journal of Pharmaceutical and Clinical Research, 6, 245-249.

[37] Nesby-O’Dell, S., Scanlon, K.S., Cogswell, M.E., Gillespie, C., Hollis, B.W., Looker, 
A.C., Allen, C., Doughertly, C., Gunter, E.W. and Bowman, B.A. (2002) Hypovitaminosis D Prevalence and Determinants among African American and White Women of Reproductive Age: Third National Health and Nutrition Examination Survey, 1988-1994. The American Journal of Clinical Nutrition, 76, 187-192. https://doi.org/10.1093/ajcn/76.1.187

[38] Mattila, C., Knekt, P., Männistö, S., Rissanen, H., Laaksonen, M.A., Montonen, J. and Reunanen, A. (2007) Serum 25-Hydroxyvitamin D Concentration and Subsequent Risk of Type 2 Diabetes. Diabetes Care, 30, 2569-2570. https://doi.org/10.2337/dc07-0292

[39] Grimnes, G., Emaus, N., Joakimsen, R.M., Figenschau, Y., Jenssen, T., Njølstad, I., Schirmer, H. and Jorde, R. (2010) Baseline Serum 25-Hydroxyvitamin D Concentrations in the Tromsø Study 1994-95 and Risk of Developing Type 2 Diabetes Mellitus during 11 Years of Follow-Up. Diabetic Medicine, 27, 1107-1115. https://doi.org/10.1111/j.1464-5491.2010.03092.x

[40] Pittas, A.G., Nelson, J., Mitri, J., Hillmann, W., Garganta, C., Nathan, D.M., Hu, F.B. and Dawson-Hughes, B. (2012) Diabetes Prevention Program Research Group. Plasma 25-Hydroxyvitamin D and Progression to Diabetes in Patients at Risk for Diabetes: An Ancillary Analysis in the Diabetes Prevention Program. Diabetes Care, 35, 565-573. https://doi.org/10.2337/dc11-1795

[41] Hyppönen, E. and Power, C. (2006) Vitamin D Status and Glucose Homeostasis in the 1958 British Birth Cohort: The Role of Obesity. Diabetes Care, 29, 2244-2246. https://doi.org/10.2337/dc06-0946

[42] Plotnikoff, G.A. and Quigley, J.M. (2003) Prevalence of Severe Hypovitaminosis D in Patients with Persistent, Nonspecific Musculoskeletal Pain. Mayo Clinic Proceedings, 78, 1463-1470. https://doi.org/10.4065/78.12.1463

[43] Earthman, C.P., Beckman, L.M., Masodkar, K. and Sibley, S.D. (2012) The Link between Obesity and Low Circulating 25-Hydroxyvitamin D Concentrations: Considerations and Implications. International Journal of Obesity, 36, 387-396. https://doi.org/10.1038/ijo.2011.119

[44] Kayaniyil, S., Retnakaran, R., Harris, S.B., Vieth, R., Knight, J.A., Gerstein, H.C., Perkins, B.A., Zinman, B. and Hanley, A.J. (2011) Prospective Associations of Vitamin D with $\beta$-Cell Function and Glycemia: The Prospective Metabolism and Islet Cell Evaluation (PROMISE) Cohort Study. Diabetes, 60, 2947-2953. https://doi.org/10.2337/db11-0465

[45] Gao, Y., Wu, X., Fu, Q., Li, Y., Yang, T. and Tang, W. (2015) The Relationship between Serum 25-Hydroxy Vitamin D and Insulin Sensitivity and $\beta$-Cell Function in Newly Diagnosed Type 2 Diabetes. Journal of Diabetes Research, 2015, Article ID: 636891.

[46] Johnson, J.A., Grande, J.P., Roche, P.C. and Kumar, R.A. (1994) Immunohistochemical Localization of the 1,25(OH)2D3 Receptor and Calbindin D28k in Human and Rat Pancreas. American Journal of Physiology-Endocrinology and Metabolism, 267, 356-360. https://doi.org/10.1152/ajpendo.1994.267.3.E356 